\title{
Využití pojmových map s následným rozhovorem jako vý- zkumného nástroje při hledání žákovských miskoncepcí
}

\author{
Věra Pavlátová
}

Envigogika 14 (1) - Inspirace/ Inspiration

Publikováno / Published 20. 5. 2019

DOI: $10.14712 / 18023061.591$

\begin{abstract}
Abstrakt
Článek ilustruje tvorbu a reflexi pojmových map (= PM) ve výzkumu publikovaném v tomto čísle Envigogiky („Dětská pojetí vybraných environmentálních fenoménů u žáků 1. a 2. stupně základní školy"). Zde byly pojmové mapy a následný doplňující rozhovor využity k analýze porozumění významu vybraných fenoménů. Každý žák měl nejprve pochopit, co je pojmová mapa, a mohl si vyzkoušet, jak se vytváŕí. Pro účely výzkumu pak zpracoval vlastní pojmovou mapu, vždy kolem vybraného centrálního fenoménu (celkem jich bylo 8 ). $\checkmark$ rámci následujícího rozhovoru s výzkumníkem tento žák vysvětloval své myšlenkové operace $v$ PM, př́padně pomocí návodných otázek ještě dále pokračoval $v$ rozboru. $O$ použité metodě více vypovídá související článek; zde přinášíme príklad tvorby pojmových map a průběhu rozhovoru s jedním ze žáků a zobecnění všech provedených rozhovorů.
\end{abstract}

\section{Klíčová slova}

dětská pojetí; environmentální výchova; ekologické fenomény; miskoncepce; pojmová mapa; rozhovory s žáky.

\section{Abstract}

The article illustrates creation and reflection of conceptual maps (= CM) in the research published in this issue of Envigogika ("Children's conception of selected environmental concepts in pupils of the primary and lower-secondary school"). Here, conceptual maps and a follow-up interviews were used to analyze the understanding of the importance of selected phenomena. Every pupil should first understand what a conceptual map is, and could try to create it. For the purpose of the research, he then elaborated his own conceptual map, always around the selected central phenomenon (in total there were 8). In the following interview with the researcher, this pupil explained his CM's thought operations, or continued to analyze them using guiding questions. The related article is more relevant to understand the method used; here we present an example of creating conceptual maps and the course of an interview with one of the pupils and generalizing all the interviews.

\section{Key words:}

children's conception; conceptual map; environmental education; ecological phenomena; misconception; interviews with pupils. 


\section{Úvod}

Pojmové mapy jsou nejen výzkumným nástrojem, který umožňuje vizualizaci procesu učení (Nuutinen \& Sutinen, 2003) a pomáhá tak učitelům v diagnostice dětských pojetí (Prokša, 2007; Schubertová \& Bednárová, 2018). Jejich použití současně přispívá k porozumění významu zobrazovaných fenoménů samotnými žáky, a pomáhají jim tak kriticky uvažovat o jejich zkušenostech a miskoncepcích, a tím rozvíjejí jejich kognitivní schopnosti (Novak \& Gowin, 1984; Holcomb \& Shonka, 1993; Irvine, 1995). Jestliže související text (Pavlátová, 2019) popisuje využití PM jako výzkumného nástroje, z následujícího přepisu rozhovoru výzkumníka $s$ žákem se můžeme dozvědět více o myšlenkových pochodech vedoucích $k$ (ne)porozumění danému fenoménu, i způsobu, jak Ize prípadné miskoncepce překonat, na straně žáka. Výsledky pojmového mapování a následných rozhovorů jsou zde též shrnuty a zobecněny.

Vlastní postup přípravy rozhovoru byl následující: po pečlivé analýze pojmových map $(N=79)$ následoval u vybraných respondentů $(N=4)$ ještě přibližně po 1 měsíci rozhovor $s$ výzkumníkem, kde $R$ vysvětlovali své myšlenkové operace $v$ PM, př́padně pomocí návodných otázek ještě dále pokračovali $v$ rozboru. Použili jsme tedy metodu retrospektivních a prüběžných verbálních odpovědí; respondenti „uvažovali nahlas", vypovídali o svých myšlenkových operacích (Gavora, 1996. s. 73).

Raport (Gavora, 2010) nebyl nutný, respondenti výzkumníka ze školy dobře znají, i když ani jednoho přímo neučí. Všichni respondenti byli předem připraveni na probíhající rozhovor, výzkumníkem i rodiči.

Respondent č. 1 chodil do tř́dy 3. A8 (ekvivalent 8 . tř́dy ZŠ), bylo mu 14 let; je to chlapec; jeho oblíbenými předměty jsou biologie a chemie; na posledním vysvědčení měl $z$ biologie 1 , chemie 2 a zeměpisu 3 . Do prírody chodí $3 x$ týdně, bydlí $v$ domě se zahradou, má domácí zviřata (pes, morče, křeček, ryby), o které se sám stará. Testy se mu povedly, $v$ testu A získal 36 bodů, $v$ testu $B 32$ bodů (z maxima 40 bodů). Dle soudu jistoty mu výrazně obtížnější připadal test $B$, kde si odpovědi volil (škála testu $A 73$ bodů, škála testu B 38 bodů).

V rámci vyhodnocování kvalitativního výzkumu došlo i ke kategorizaci dat a kódování odpovědí. Každý kód znamená jeden typ odpovědi (Strauss \& Corbinová, 1999; Gavora, 2010; Hendl, 2016).

Vysvětlivky k analýze rozhovoru a pojmových map (jedná se o autentický záznam):

- správné směry (správné pojetí): zelená barva + písmenko S

- miskoncepce (mylné pojetí): červená barva + písmenko M

- neutrální směr (neutrální či nesouvisející pojetí): žlutá barva + písmenko $\mathrm{N}$

- klíčové fenomény: černá barva rámečku.

AUTENTICKÝ ZÁZNAM (neproběhla zde korektura, obsahuje i hovorové výrazy)

V: Víš, proč tady jsi, pamatuješ si, co jsme spolu vytvářeli?

R: No, něco $s$ tou environmentální výchovou.

V: Ano, my jsme spolu dělali výzkum ohledně pojmů z environmentální výchovy, nejprve jste vyplňovali takový test složený ze dvou částí, tady mám ten tvůj; a pak jste vytvářeli takovéto diagramy, věděl bys, jak se jmenují? Pamatuješ si to ještě?

R: Myšlenková mapa. 
V: Správně, myšlenková, nebo pojmová mapa. To znamená, že si tady vždycky měl znázornit tvé myšlenky k tomu vybranému pojmu. Já bych ted' od tebe potřebovala, abys mi vysvětlil ty tvé myšlenky, proč si takto postupoval, proč si to takto napsal. Protože to je myšlenková mapa, tok tvých myšlenek, tak abych ráda věděla, co tě k tomu vedlo, že si z toho základního pojmu vymyslel ty ostatní. Tady jsou i nějaké šipky, některé vedou k pojmu, některé opačně.

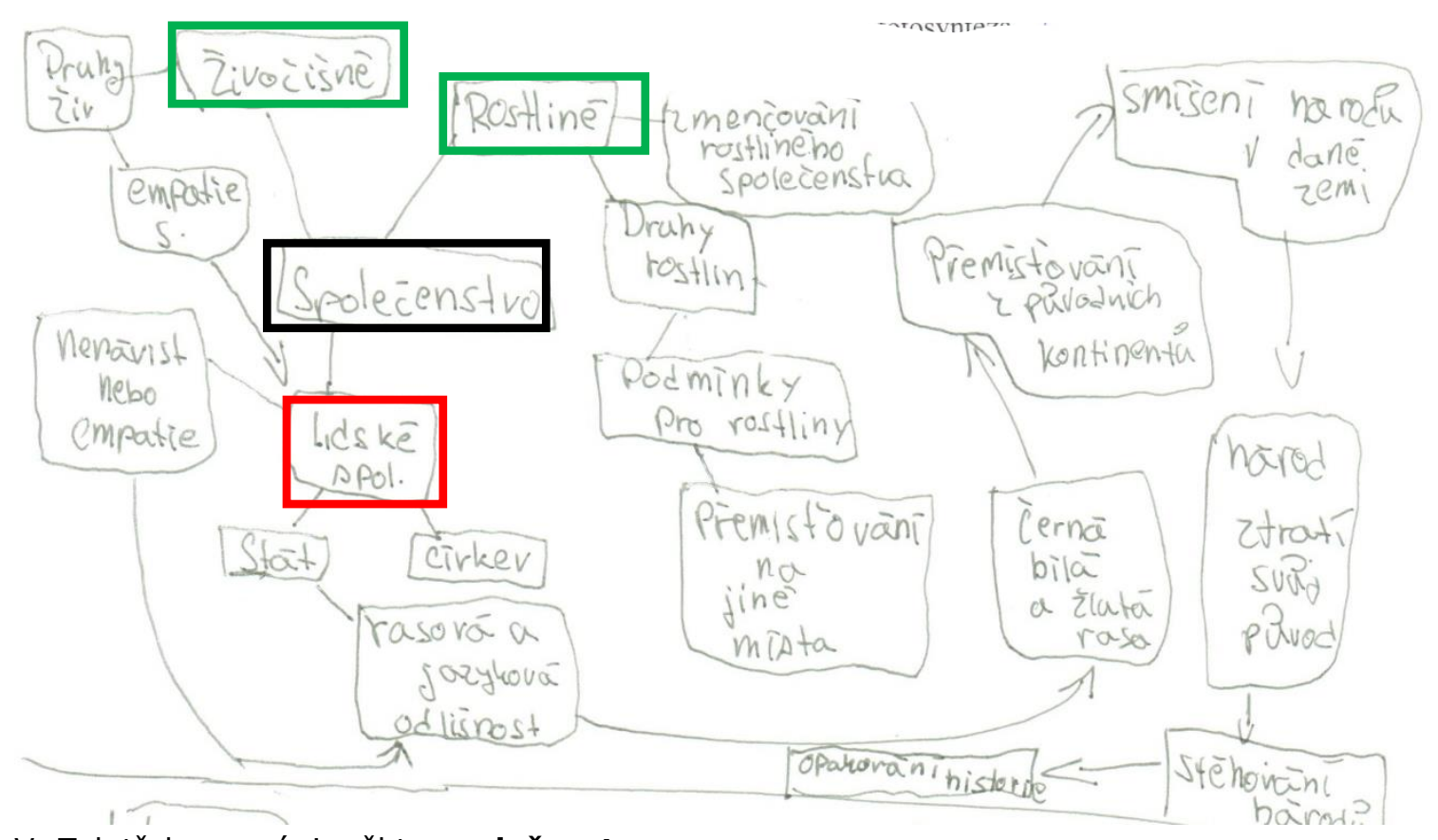

V: Tak třeba první si měl to společenstvo.

R: Tak to mě napadlo rostliny, protože jsem si vzpomněl na př́rodu a pak jsem si vzpomněl, že je to zmenšování rostlinného společenstva kvůli různé výstavbě a znečištování přírody. Pak jako druhy rostlin, protože každé společenstvo jakoby je jakoby z jiných druhů, takto jsem to myslel. S1

V: Takže společenstvo je tvořeno různými druhy.

$\mathrm{R}$ : Ano. $\mathrm{S} 1$

$\mathrm{V}$ : Dobře.

R: Pak jako podmínky pro ty rostliny, jako že každý druh má jiné podmínky pro život (S1), ta rostlina; a to přemist́ování na jiné místo, to jsem myslel, že někde by mohly být ty rostliny parazitické. N1

V: Hm, fajn. A proč máš $v$ tom společenstvu i to živočišné?

R: Ehmmm, protože mi to připadalo taky, že ehmmmm.

V: Jako, že existuje rostlinné i živočišné společenstvo?

R: Ano. S1

$\mathrm{V}$ : A jak jsi přišel potom na tu lidskou společnost?

R: Živočichové.

V: Jako že patří do živočichů i lidé?

R: Ano.

V: Nebo tady ti vede ta spojovací čára i z toho společenstva, tak jak jsi to myslel?

R: No jako že je lidský společenství, ale zároveň se to pojí trošku i s tím živočišným. M1

V: Aha, jako že třeba $v$ jiných předmětech je společenstvo bráno jako to lidské, myslíš.

A v biologii je spíše jako živočišné a rostlinné. Nebo jak jsi to myslel?

R: No, ano, že v biologii hlavně to rostlinné a živočišné a že to živočišné se úzce pojí s tím lidským. N1 


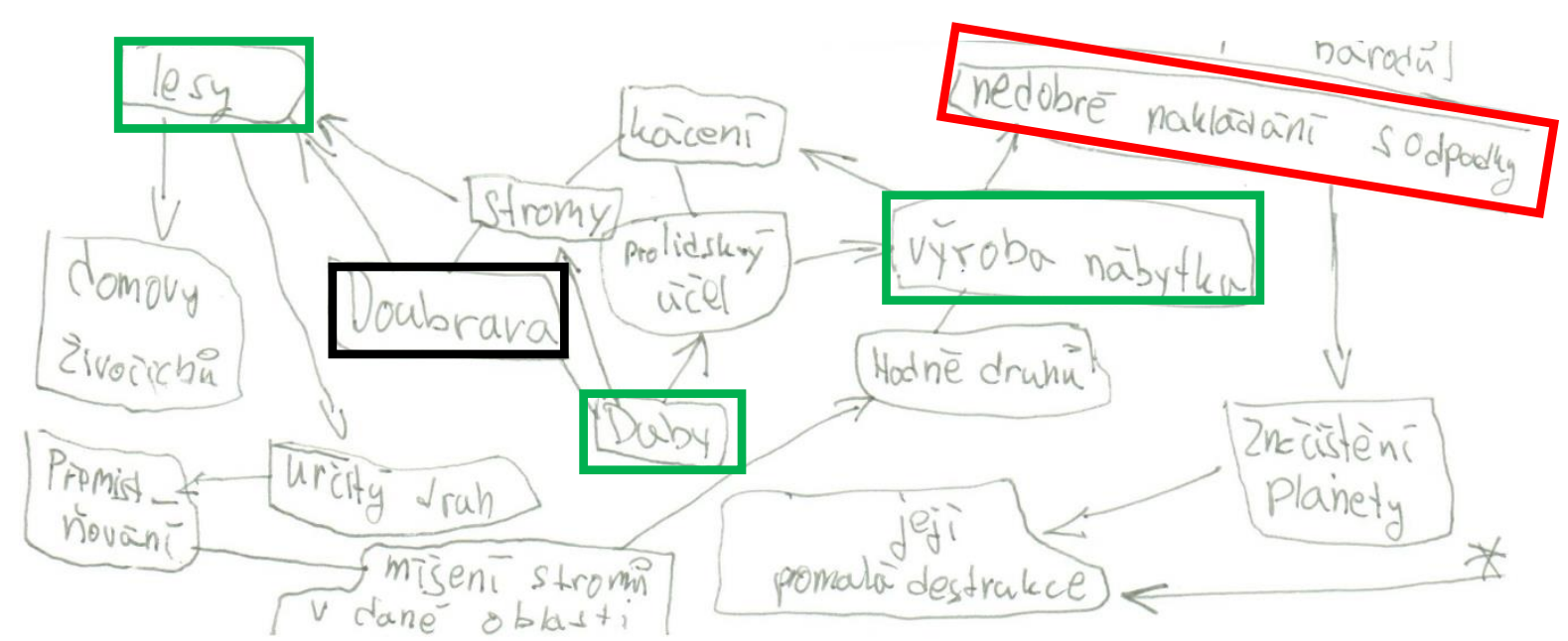

V: Dobře, dalším pojmem byla doubrava.

R: Jo, to jsem, doubrava že to je dubový les. S2

V: Takže z čeho si vycházel? Les že to je.

R: Který je vysázen výhradně z dubů (S2). Že většinou, když se tak na to koukám, že jako to dřevo, které se $z$ něho vytěži (S2), tak je většinou pro lidské účely. N2

V: Aha a vyrábí se $z$ něho třeba...

R: Nábytek (S2). A pak výroba... když se třeba mění $v$ domácnosti často nábytek, tak ten nábytek se třeba veze do Sběrnýho dvora nebo takhle, a tím se jako podporuje ta spotřeba toho N2

V: A to nedobré nakládání s odpady, to jsi myslel jak?

R: No právě že je to podněcování té větší výroby třeba, toho nábytku, tím pádem toho těžení dřeva. Lidi jakoby furt kupují nový. M2

V: Tak ten starý většinou vyhazují. A tou výrobou nábytku dochází tedy k nějakému znečištění planety, nebo to jsi myslel tak, že se ten starý nábytek dává do toho sběrného dvora?

R: Tady jsem už myslel odpadky jako celkově, že je to znečištění. N2

V: Jo. Ten domov živočichů to je obecně jako že les. N2

R: Jo.

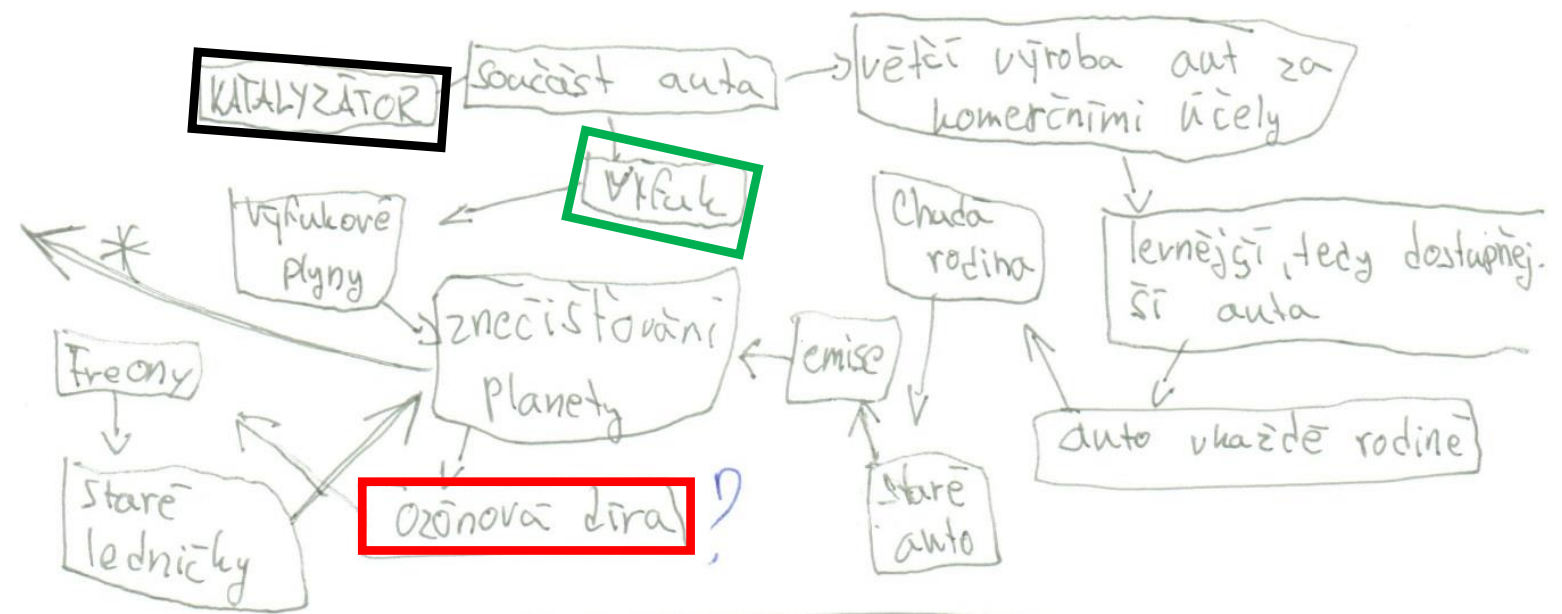

V: Dobře, tak další pojem jsme měli katalyzátor, ten máš tady.

R: Jo, to jsem dal asi jako součást toho auta, výfuk. S3

V: Takže, kde je $v$ autě ten katalyzátor?

R: U výfuku. S3

V: U výfuku a proč tam je? Proč to máš takto znázorněno, v té mapě? 
R: On čistí jakoby (M3), no ten výsledný plyn, co vyjde z toho auta, není jakoby tak škodlivej. S3

V: Správně, kvůli tomu se ten katalyzátor tam i dává, že jo?

R: Jo.

V: No a ted' už jste trošku pokročili v chemii a dovedl bys tedy vysvětlit, kde se ten pojem katalyzátor vyskytuje $v$ chemii? Protože i ten katalyzátor $v$ autě se jmenuje podle jedné schopnosti, co umí, kterou si právě ted'ř́íkal.

R: Nějaká filtrační látka. M3

V: No to je látka, co urychluje reakce, takže on urychluje spalování plynů na ty méně škodlivé látky. Učili jste se to už v chemii, nebo neučili?

R: To nevím.

V: V souvislosti s tou chemií si to nepamatuješ?

R: Katalyzátor si myslím, že jsme tam měli minulý rok.

$\mathrm{V}$ : Ale nepamatuješ si to, pamatuješ si to jen $v$ souvislosti s tím autem.

R: To spíš.

V: Tak proč tady máš „ozonová díra" napsané, v souvislosti s tím katalyzátorem?

R: Kvůli znečištování planety, když ta uhlíková stopa mění jakoby, nebo ten jako ta

stopa, co vychází z výfuku, znečištuje planetu a zvětšuje ozonovou díru. M3

V: Zvětšuje ozonovou díru?

R: No, znehodnocuje se, oni ty freony nějak měnily ozon. N3

V: To máš pravdu, to jste se učili, že freony mění ozon. A myslíš si, že ty freony nějak souvisí $\mathrm{s}$ tím autem, s tím katalyzátorem?

R: To ne.

V: To nesouvisí, že jo?

R: V tom znečištování jo, ale s katalyzátorem ne.

V: Tak jestli ty výfukové plyny z auta tedy zapříčiňují tu ozonovou díru? Co myslíš?

R: Myslím, že jo. M3

V: A proč myslíš, že jo?

$\mathrm{R}:[\mathrm{mlči}]$

V: Tak ř́́kal jsi, že tu ozonovou díru zapříčiňují freony, a ty freony se vyskytují třeba, tady to máš napsané.

R: V ledničkách N3

V: V ledničkách, ano; a vyskytují se i v těch výfukových plynech, nebo tam je něco jiného?

R: Tam je uhlík. M3

V: No, tam je oxid uhličitý. A způsobuje oxid uhličitý ozonovou díru, nebo způsobuje něco jiného?

$\mathrm{R}$ : Ne, ten nezpůsobuje.

V: No a věděl bys, co způsobuje?

R: Kyselé deště. M3

V: Kyselé deště taky ne, to může jen částečně způsobovat kyselé deště, ale pak je ještě takový problém, protože ten oxid uhličitý odráží zpátky na Zem záření, takže co způsobuje? R: Skleníkový efekt. N3

V: Skleníkový efekt; takže tys popletl skleníkový efekt s ozonovou dírou, ale z toho si vůbec nic nedělej, protože to si pletou i dospělí, i vysokoškolští studenti, na to jsou už výzkumy, to se takhle stává. Tak, tady máš "emise", kde se tam vzaly ty emise?

R: Právě těch výfukových plynů. S3

V: Hmm. A že máš tu šipku směrem ke znečištování?

R: No to mám tady právě.

V: Jo, to máš od toho starého auta. To jako, že to staré auto nemá katalyzátor, jsi myslel?

R: Že tam jsou větší ty emise. S3 
V: Jo, že tam jsou větší ty emise. No, tak to máš dobře, to máš nějakou zkušenost s těmi emisemi? Víš, že se měří emise v autech, nebo proč si to myslíš, že jsou u starého auta větší emise?

R: Protože to auto jakoby nedokáže dobře spálit ten benzín. Jako to palivo.

$\mathrm{V}$ : Že už je opotřebovanější ten mechanismus, myslíš.

R: No, když je to auto starší, tak ještě nemá tak vyvinutější..., jako že ještě není tak zdokonalený. S3

V: Myslíš, že ty katalyzátory se liší i rokem výroby toho auta, že pak jsou dokonalejší.

R: Jo.

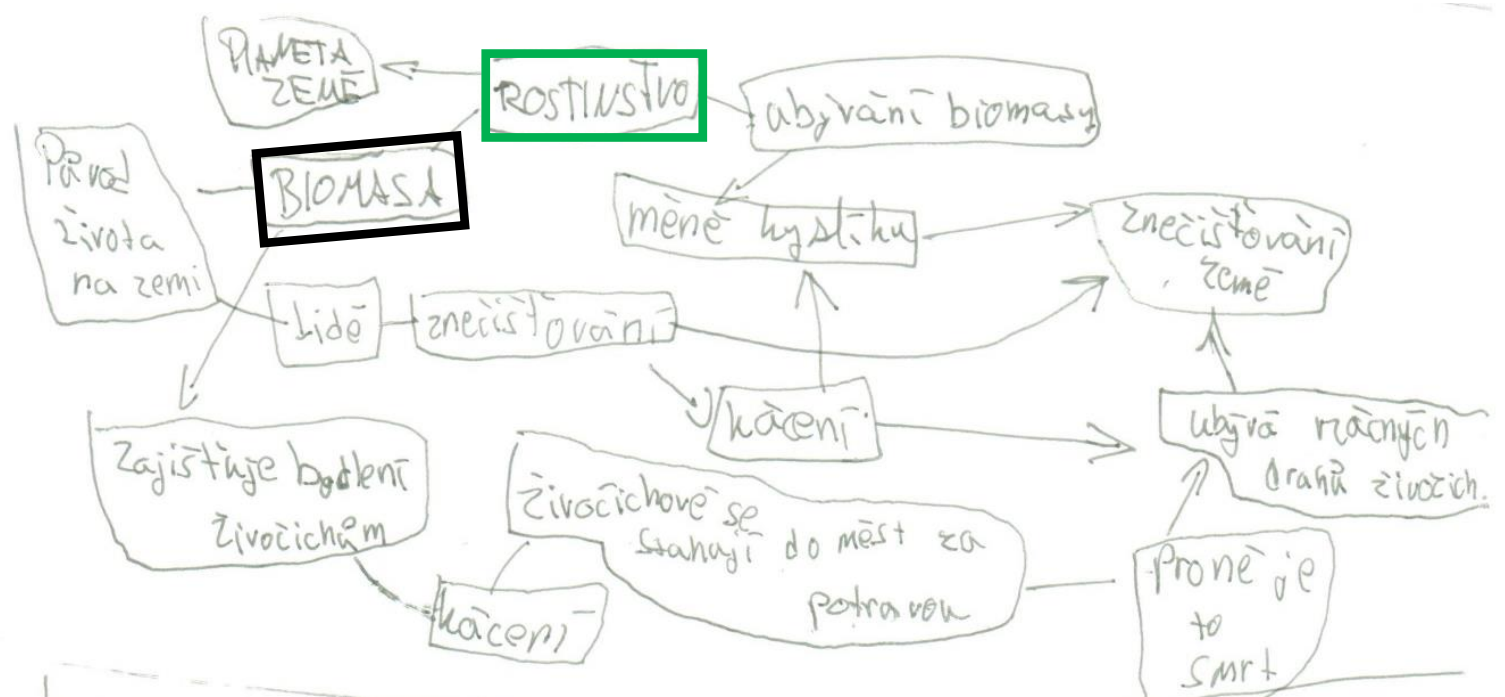

V: Tak, potom jsme měli pojem biomasa, tady. Tak proč si takto udělal tu myšlenkovou mapu?

R: Třeba biomasa že je jakoby všechno rostlinstvo (S4). To je jeden ze základních pilírư planety Země, k životu na Zemi. S4

V: Tak, proč máš tady ubývání biomasy?

R: Právě kvůli těžbě dřeva, nebo rozšiřování pozemků, stavění nových domů. S4

V: A když ubývá biomasy, tak je tady podle tebe méně.

R: Kyslíku. S4

$\mathrm{V}$ : Hmm. A ta biomasa je jenom z rostlinstva?

R: Ne, ta je i ze živočichů. S4

$\mathrm{V}$ : A máš tady ty živočichy, někde, že je ta biomasa i z živočichư?

R: To tady mám.

V: Tak tady máš něco o živočiších, že se stahují do měst za potravou (N4). A jakým způsobem biomasa zajištuje bydlení živočichů?

R: Nevím, třeba když je strom a v něm bydlej nějací ptáci, tak, to je, že ta biomasa zajištuje, že tam maj. N4

V: Že tam mají úkryt, rozumím tomu dobře?

R: Hmm.

V: Používají lidé ještě k něčemu tu biomasu?

$\mathrm{R}$ : Na výrobu různých svých různých prostředků. N4

$\mathrm{V}$ : Ano, a nebo, když to jsou různé štěpky, tak se může i spálit a vyrábět se $z$ ní.

R: Biopalivo. S4

V: Biopalivo, energie. 


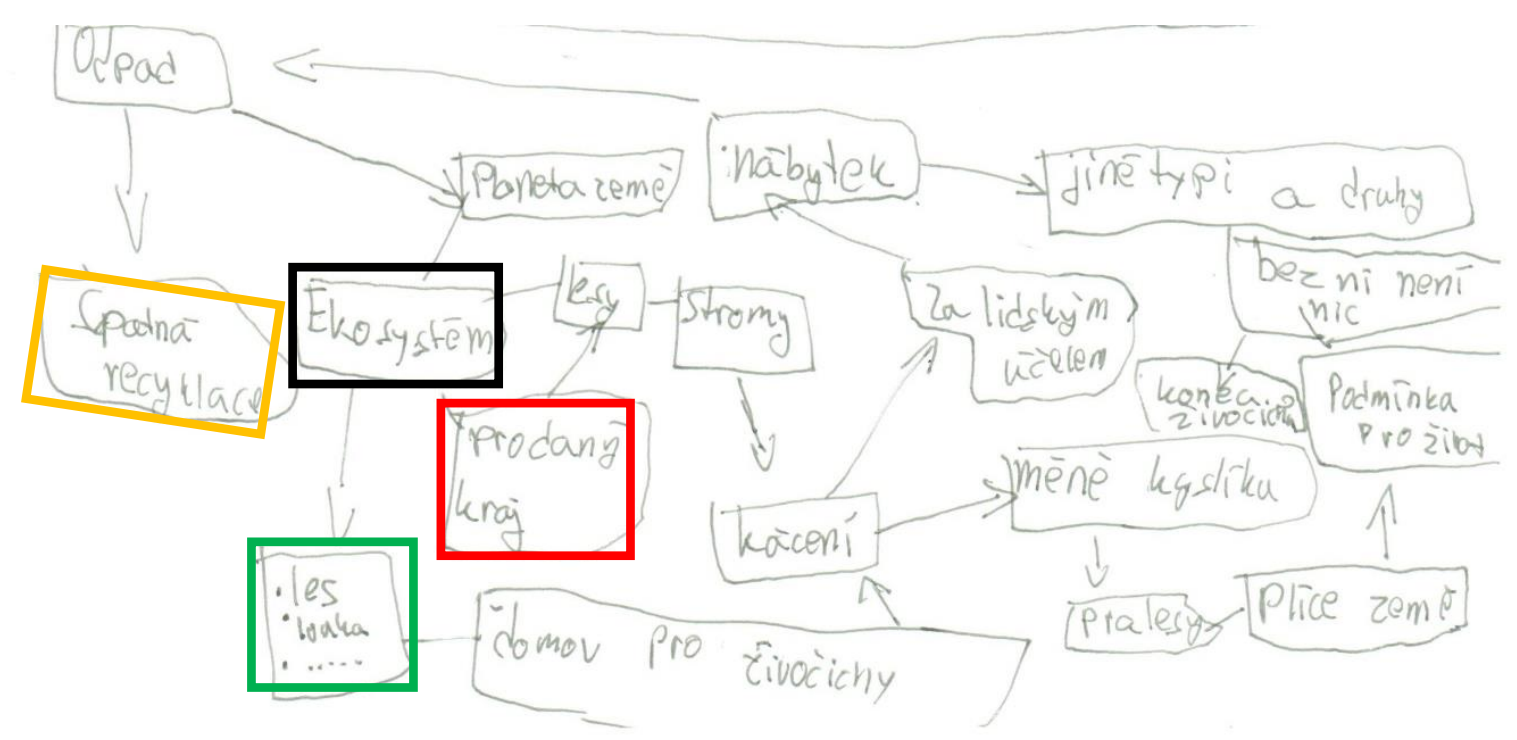

V: Tak, potom máme „ekosystém". Tak to mi vysvětli tedy, jak jsi myslel ten ekosystém.

R: Jako že máme na Zemi nějaký ekosystém, který tady funguje. N5

$\mathrm{V}$ : A je tady jenom jeden, nebo je víc ekosystémů na Zemi?

R: Je více. S5

$\mathrm{V}$ : A jaké třeba mohou být ekosystémy na Zemi?

R: Třeba vodní ekosystém. S5

V: Hmm.

R: Nebo různý tropický deštný ekosystémy. S5

V: Ano. A co všechno do toho ekosystému patří?

R: Jako celkově biomasa. Rostliny i živočiši. N5

V: A tam už jsi měl před tím tu pojmovou mapu společenstvo a tam jsme říkali, že jsou rostliny a živočichové. A čím se tedy liší společenstvo a ekosystém?

R: Ekosystém funguje tak jakoby nějakou řetězovou reakcí (N5), třeba, nevím, jak to vysvětlit.

V: No, společenstvo je $v$ tom ekosystému a co ještě je v tom ekosystému navíc, kromě toho společenstva, co myslíš?

R: [mlčí]

V: Když jsi měl třeba ten tropický deštný prales, tak tam jsou ty stromy a rostliny a živočichové a co tam ještě je? Aby ten kus planety fungoval jako ekosystém, tropický deštný prales, tak tam ještě musí být něco jiného. Co tam ještě musí být? To společenstvo je taková živá složka, že jo a co tam ještě musí být?

R: Neživá. S5

V: Jo a co je třeba neživá složka?

R: Nějaká pưda. S5

V: Správně; voda, vzduch. Takže tam si trošku udělal chybu, že tam právě nemáš tu neživou složku. A jinak tady si už zase hezky vysvětlil, co se stane, když ubývá těch ekosystémů. Co znamená ten prodaný kraj (M5), vzpomeneš si, jak si to myslel?

R: Nevím, proč jsem to napsal.

V: To si nevzpomeneš asi, vid'. 


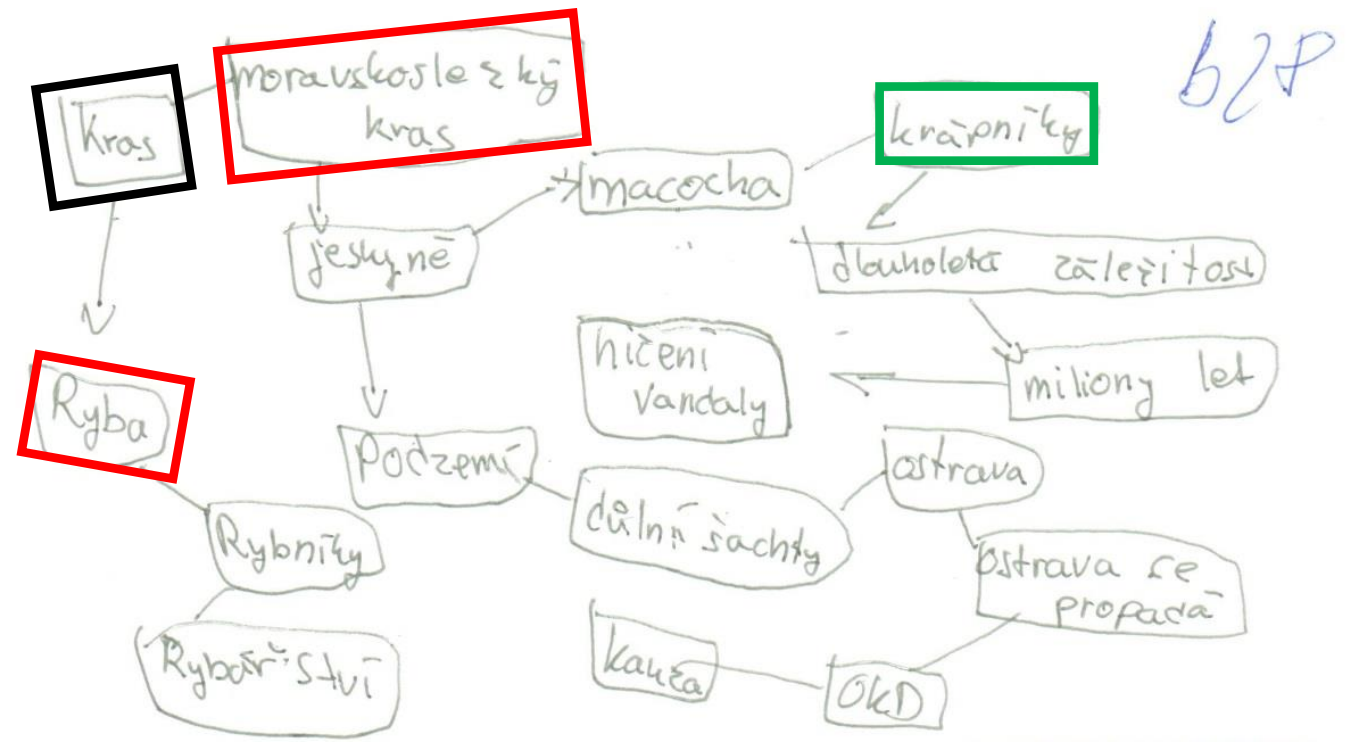

V: A potom dále jsme měli „kras", ten je tady.

R: Jo, to jsem si vzpomněl jakoby, že ho máme v Český republice. S6

V: No a myslíš, že je to Moravskoslezský kras, že se takto jmenuje?

R: No, nějak tak. M6

V: Moravskoslezský je kraj, že jo.

R: Moravský. S6

V: No a pak si správně vymyslel, že to jsou.

R: Jeskyně. $\mathrm{S6}$

$\mathrm{V}$ : Jsou to jeskyně, ve kterých jsou různé.

R: Krápníky. S6

V: Ano, skalní útvary, ve kterých jsou třeba krápníky, že ty krápníky, aby se vytvořily, že to je.

R: Trvá to dlouze. S6

V: Ano, je to dlouholetá záležitost, proto také nechceme, aby je ničili vandalové. Tak, k jeskyni máš potom dál napsáno podzemí.

R: Podzemí. S6

V: Z toho si vyvodil tedy důlní šachty, Ostravu; proč tady máš „Ostrava se propadá"?

R: Protože tam jsou všude ty šachty a to město se celkově jako snižuje. N6

$V: A$ to jsi někde slyšel?

R: Ano.

V: Jo, je to možný. OKD máš tedy tu kauzu, co tam byla (N6)? Tak a ted' mi ještě vysvětli, proč z toho krasu máš tu rybu, tady? Ryba, rybníky, rybářství. M6

R: Si to nepamatuju. Já myslím, že jsem to tady asi přehodil.

V: Co jsi přehodil?

R: No já jsem to tady asi napsal špatně. Možná jsem chtěl asi napsal, že v tom krasu jsou, $\checkmark$ těch jeskyních jsou podzemní jezera. S6

V: Jo takhle, že jsou tam jezera. Mně se totiž stalo v tom výzkumu, že některý si spletli kras a karas a napsali mi, že je to ryba, tak jsem si myslela, jestli jsi to taky takhle nemyslel.

R: To nevím, asi. 


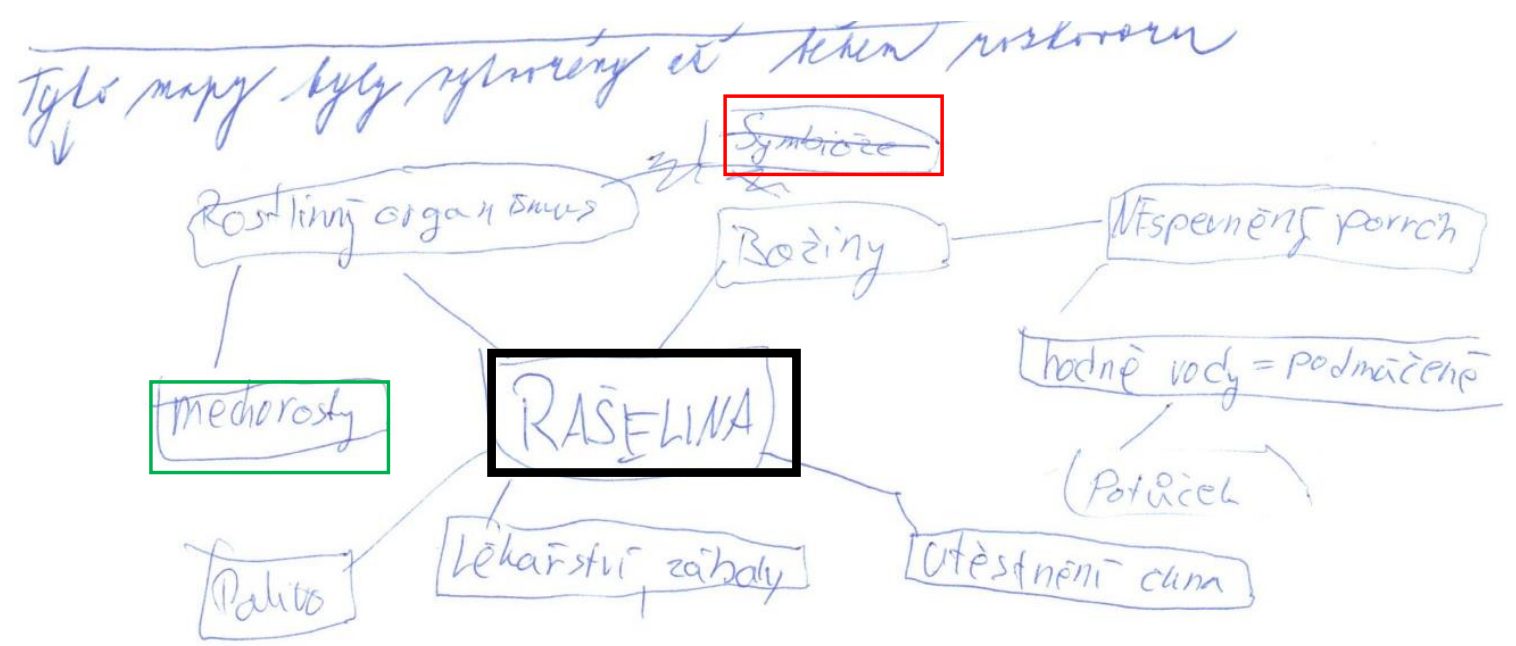

V: Takže nevíš, nevadí. Tak, potom měla být „rašelina" ještě, to jsi už nestihl? To už tady nemáš, rašelina a fotosyntéza. Byl bys tedy tak hodný, že bys to ted' napsal a rovnou bys mi říkal ty šipky? Zvládneš to? Takže rašelina.

R: No tak bažiny, nějaký nezpevněný povrch, je tam většinou hodně vody, je to podmáčený. S7

$\mathrm{V}$ : A z čeho ta rašelina vůbec je?

R: No to je rostlinný organismus (S7). Ještě že do té bažiny přitéká nějaký potůček (N7). Pak jako že je v symbióze. M7

$\mathrm{V}:$ A v symbióze je co?

R: Že v tý bažině protože tam je vlhko, tak to tam roste právě proto, že to tam je podmáčený všechno, tak se to tam vyskytuje jako. Protože mưže třeba i v rybníkách, na hladině. M7

$\mathrm{V}$ : A co se tam vyskytuje v tý symbióze?

R: To je asi blbost.

V: Co je to symbióza?

R: To je soužití dvou organismů. N7

V: No, to tam asi není, vid'. To možná jestli sis to nepletl s lišejníkem, víš. Lišejník, to je rašelina, nebo není?

R: Není. N7

$\mathrm{V}$ : Není, no, rašelina je něco jiného, z jaké je to rostliny, co myslíš?

R: Mechové. S7

V: Ano, mechorosty, zejména rašeliníky. Tak ještě by tě něco napadlo $k$ té rašelině, třeba jak ji využíváme?

R: Ona se používá v lékařství. S7

V: No, správně.

R: Nějaký masky, ne zábaly (S7). Myslím, že se dává i na střechu (S7). Ne, ve stavebnictví. [pozn. výzkumníka: http://www.chatar-chalupar.cz/zelena-strecha/]

V: Ve stavebnictví si myslíš, že se využívá?

R: Se jí těsnily dřív okna (S7). (pozn. výzkumníka: ano, rašelina se používá i jako izolace) V: Co by se z ní ještě mohlo vytvořit, co myslíš, Třeba kdyby se ještě hodně vysušila, tak na co se dá použít? Ono tam bude hodně uhlíku v té rašelině.

$\mathrm{R}$ : Jako palivo. $\mathrm{S7}$

V: Ano, jako palivo; ještě si můžeš koupit normálně rašelinu v pytlíku. A na co se to pouŽívá?

R: Podpalovač. N7

V: Ne, to už nesouvisí s tím palivem, jo, to už je další využití rašeliny. Kromě uhlíku tam jsou i další prvky. Tak to už asi nevadí, ještě ji můžou zahrádkáři používat jako hnojivo tu rašelinu. 


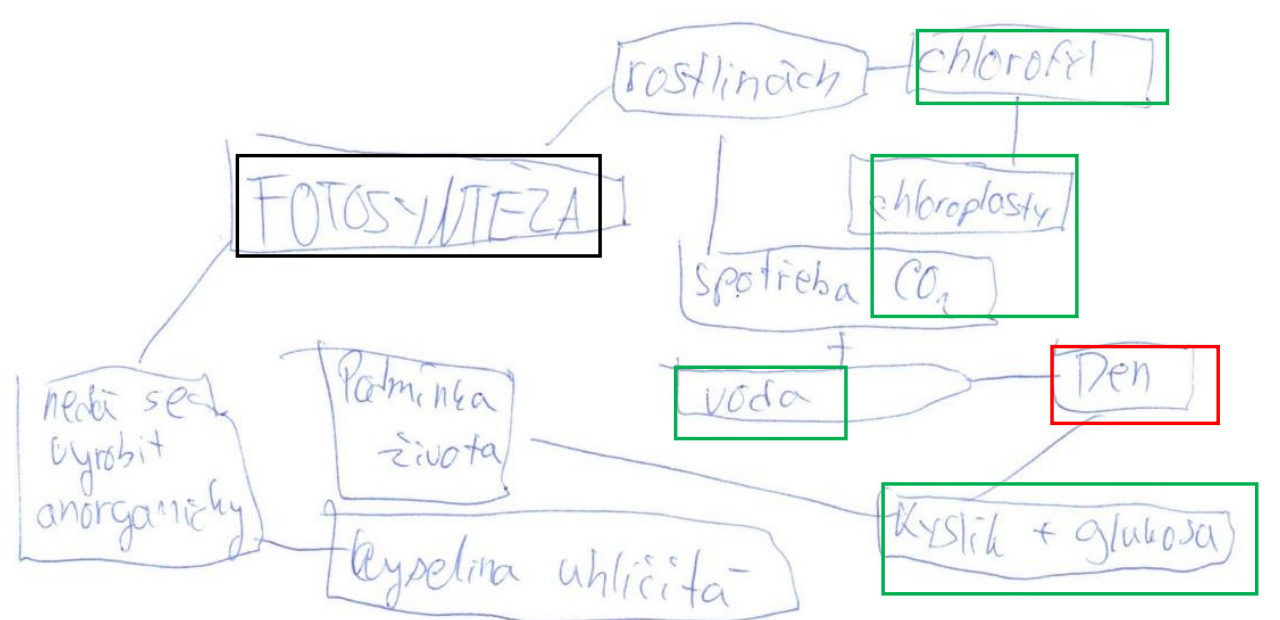

V: Tak, "fotosyntézu" kdybys tedy ještě zkusil.

R: Takže jako probíhá v rostlinách, které musí mít chlorofyl. 58

$\mathrm{V}$ : Ano, co je to chlorofyl?

R: Zelený barvivo, je v rostlinných buňkách, ve kterých jsou chloroplasty (S8). Spotřebovávaj oxid uhličitý při fotosyntéze a potřebují k tomu ještě jako vodu (S8) a ve dne (N8) právě přeměňují ten oxid uhličitý a vodu na kyslík a glukózu. S8

V: Tak ještě by tě něco napadlo $k$ té fotosyntéze, nebo si myslíš, že už tam máš všechno?

R: Jo, ještě že to je jakoby podmínka života u nás na Zemi (S8), jo, pak jako nedá se jakoby vyrobit anorganicky, protože by vznikla kyselina uhličitá. S8

V: Správně, z vody a oxidu uhličitého by vznikla kyselina uhličitá, potřebuješ k tomu tedy.

R: Chlorofyl.

V: Chlorofyl a ty Chloroplasty. Tak, já si myslím, že už jsme řekli všechno, děkuji ti moc za rozhovor.

Rozhovor trval 29 minut 8 sekund. Tvorba pojmových map, jež rozhovoru předcházela, trvala respondentovi (B28) 40 minut.

\section{Výsledky pojmových map a následných rozhovorů}

\section{Biomasa}

$\checkmark$ pojmových mapách (PM) se také objevovala miskoncepce vzniklá na základě podobnosti slova "biomaso, zdravé maso, maso bez nějakých produktů, hubnoucí maso", ale zejména u žáků 4. třídy, a to v 9 případech z 24 (37,5 \% Ž). U žáků 5. třídy se objevila jen ve 2 prípadech, na druhém stupni se neobjevila vůbec. Dále žáci spojovali správně fenomén s kompostem, hnojivem, obnovitelným zdrojem energie, topivem, palivem, organickým materiálem (tyto asociace jsou patrnější na 2 . stupni Zš).

$\checkmark$ následných rozhovorech nad některými PM jsme došli i $\mathrm{k}$ dalším správným pojetím: jde o jeden ze základních piliřru planety Země, k životu na Zemi, ovšem dochází k jejímu ubývání v důsledku těžby dřeva, nebo rozšiřování pozemků, stavění nových domů, což zapřičiňuje ubývání kyslíku. Objevila se ovšem další pojetí a miskoncepce, kdy R si fenomén "biomasa" rozdělil na "bio" (od něj odvozoval bioodpad, biologie...) a "masa" (od něj odvozoval maso, zviŕăata...). Jedna R uvedla, že nyní by už "maso" nenapsala, že již ví, že jde o přírodní energii. Další z R "obnovitelný zdroj" vysvětlil tak, že se dá znovu použít, patrně 
pojal spíše jako recyklaci (miskoncepce vzniklé na základě vlastního vysvětlení či miskoncepce vzniklá špatným pochopením učiva).

\section{Rašelina}

$\checkmark$ pojmových mapách (PM) se také objevovala miskoncepce vzniklá na základě podobnosti slova: "mrtvé zviŕe"; patrně R zaměnil "rašelina" a "mršina", anebo si fenomén spletl s fenoménem "humus". Také se $v 5$ prípadech objevila miskoncepce vzniklá špatným pochopením učiva, kdy si rašelinu R představovali jako: „něco na stromě", „zelená plíseň”, patrně došlo $\mathrm{k}$ záměně $s$ lišejníkem. Miskoncepcí spojenou se zrakovou a pocitovou představou Ize vysvětlit odpověd' R ze 4 . třídy - "kamínky, štěrk".

Dále žáci spojovali správně fenomén s bažinou, půdou, rozloženými rostlinami, mechy, hnojivem, humusem, topivem, palivem, substrátem, bahenními lázněmi (tyto asociace jsou patrnější na 2. stupni ZŠ).

Vyskytla se i zajímavá asociační propojení: rašelina $\rightarrow$ půda $\rightarrow$ hlína $\rightarrow$ hnojivo $\rightarrow$ zahradničení $\rightarrow$ pěstování $\rightarrow$ zahrada; nebo došlo k zajímavému zakomponování fenoménu „biomasa". Jiná respondentka zase propojila přes „rostlina" PM fenoménu "rašelina" a "fotosyntéza"; další probandka došla celkem logickou cestou od rašeliny přes přesličky, paleontologii a dinosaury až k seriálu "Přátelé".

V následných rozhovorech nad některými PM jsme došli i k dalším správným pojetím: jde o podmáčený povrch, rašelina se využívá v lékařství, ve stavebnictví (tzv. zelené střechy, nebo izolace). Objevila se ovšem i některá další pojetí a miskoncepce, kdy použití rašeliny coby palivo evokovalo i možnost, že by se prodávala jako podpalovač, nebo respondent uvažoval o symbióze rašeliny. $V$ tomto případě došlo patrně $k$ záměně $s$ lišejníkem, stejně jako u dalšího rozhovoru s jiným respondentem. Respondentka, která pủvodně (samostatně) pojmovou mapu vůbec nevytvořila, na základně rozhovoru vytvořila správnou pojmovou mapu, při jejíž tvorbě jí významně evokovala vzpomínka na školní exkurzi do botanické zahrady.

\section{Kras}

$\checkmark$ pojmových mapách (PM) se také objevovala miskoncepce vzniklá na základě podobnosti slova "kras × kraj", a to např́ćc třídami, celkem se tato miskoncepce objevila v 17 případech $(21,5 \% R)$, nejvíce u žáků 4 . třídy, a to $v 6$ případech. $U$ žáků 5 . třídy se objevila jen ve 2 prípadech, na druhém stupni se neobjevila vůbec. Tato miskoncepce pak R zavedla v PM dvěma směry; bud' začali vyjmenovávat kraje ČR, nebo dále pokračovali na fenomén "krajina", který následně dále rozvedli. Další miskoncepce vzniklá na základě podobnosti slova byla "kras “ karas", která pokračovala potom rybníkem a rybářstvím. Miskoncepce spojená se zrakovou a pocitovou představou evokovala "kras" jako krásné místo, jedna z respondentek pak následně v PM popsala "krásy Moravy" včetně tradic a zvyků. Dále žáci velmi často spojovali správně fenomén s Českým a Moravským krasem ( $v 17$ př́padech, 21,5\% R), jeskyněmi, skalními útvary, chráněnou oblastí. Žáci 9. třídy již byli schopni vyjmenovat i některé druhy krápníků.

V následných rozhovorech nad některými PM jsme došli i již k výše zmíněným pojetím (navíc se objevila jen zmínka o časové náročnosti vzniku krápníků a o vandalismu) a miskoncepcím (ryba; krajina; krása). Respondentka ze 4. tř́́dy ZŠ věděla, že jde o skalní útvar z vápence, dokonce znala i názvy krápníků; stalaktity a stalagnáty. 


\section{Katalyzátor}

$\checkmark$ pojmových mapách (PM) se nejčastěji objevovalo pojetí vzniklé kvůli vícevýznamnosti fenoménu, že je "katalyzátor součástka v autě" - takto odpovídalo $21 \mathrm{R}(26,6 \%)$, nejvíce žáci 5 . a 8. tř́́dy. Toto pojetí $R$ bud' zavedlo správným směrem na výfuk, výfukové plyny, nebo se mylně domnívali, že se katalyzátor vyskytuje $v$ motoru, nebo nádrži auta. Někdy směr, že je katalyzátor "sít́ka ve výfuku" zavedlo R na miskoncepci, že je katalyzátor filtr, který čistí ovzduší, zachycuje nečistoty (miskoncepce vzniklá špatným pochopením učiva).

Také se v PM objevovaly miskoncepce vzniklé na základě podobnosti slova: „deratizátor", ",katapult". Miskoncepcí spojenou se zrakovou a pocitovou představou Ize vysvětlit odpověd'R ze 4. třídy - "kohoutek", kterou rozvedl do směru: kohoutek $\rightarrow$ potrubí $\rightarrow$ řeka $\rightarrow$ kanál. Miskoncepce ze stejné kategorie evokovala v $6 \mathrm{R}$ "stroj", který následně rozvedli do směru kovu, továrny či elektrárny.

Dále žáci spojovali správně fenomén s emisemi a imisemi. Analyzovaný fenomén uvedli v PM v souvislosti s chemickou reakcí jen $2 \mathrm{R} z \mathrm{8}$. třídy. Jeden $\mathrm{R} z \mathrm{~g}$. tř́́dy uvedl zajímavé a správné pojetí, fenomén katalyzátor rozdělil na "mechanický vyskytující se $v$ autech" a "přírodní vyskytující se v živých tvorech a rostlinách" (patrně šlo o enzymy).

V následných rozhovorech jsme došli i k dalšímu správnému pojetí, že "výsledný plyn, co vyjde z toho auta, není tak škodlivý", ovšem toto pojetí pokračovalo mylnou domněnkou, že katalyzátor funguje jako filtrační látka. Objevila se ovšem i další miskoncepce, že "výfukové plyny z auta zapříčiňují ozonovou díru". Po další části rozhovoru s použitím návodných otázek si R uvědomil existenci freonů a problematiku ubývání ozonu; správně vydedukoval, že výfukové plyny obsahují oxid uhličitý, opět si ovšem nebyl jist problematikou (nejprve určil kyselé deště, pak teprve skleníkový efekt). Dalším pojetím bylo, že katalyzátor je nádrž (na vodu i jiné látky), která se vyskytuje $v$ domácnosti, ale může být i venku, i zahrabaná pod zemí.

\section{Ekosystém}

$\checkmark$ pojmových mapách (PM) se také objevovala miskoncepce vzniklá na základě vlastního vysvětlení či spojená se zrakovou a pocitovou představou, že jde o "systém, který pomáhá prírodě zejména $v$ oblasti třídění odpadu", takto odpovědělo $22 \mathrm{R}(28 \%)$, nejvíce jich bylo z 8. třídy (14). Vysvětlení je prosté; respondenti totiž chodí do školy, která je Ekoškolou a vytvořený Ekotým žáků zde kontroluje, zda ve třídách správně třídí odpad. Ze stejného důvodu někteří R zapojovali do PM i ochranu prírody a projekty Green a Blue Life, kterým se na škole nadstandardně věnují.

Dále žáci velmi často uváděli v PM jen živou složku ekosystému (18 R, 22,8 \%), nebo se omezili jen na výčet různých typů ekosystémů (13 R, 16,5\%).

V následných rozhovorech nad některými PM jsme došli i k dalším správným pojetím; že ekosystém je tvořen biomasou (došlo tedy k propojení analyzovaných fenoménů) a že ekosystém musí fungovat na základě určitých vztahů mezi složkami. Jedna z R upozornila i na souvislosti $v$ ekosystému, například na potravní řetězec. Objevila se ovšem i již výše zmíněná miskoncepce, analogie mezi ekosystémem a Ekotýmem, ekokodexem (soubor pravidel vytvořených žáky Ekoškoly), dobrovolné činnosti ohledně třídění odpadu a pomoci př́rodě. 


\section{Společenstvo}

I v pojmových mapách (PM) se objevovaly miskoncepce vzniklé kvůli vícevýznamnosti fenoménu či vzniklé na základě podobnosti slova nebo spojené se zrakovou a pocitovou představou, kdy R chápali společenstvo jako kolektiv, lidi, přátele, rodinu, skupinu, společnost, kterou dále rozvíjeli v rámci dalších vztahů (přátelství, nenávist, třída, týmová práce, barva pleti...). Takto uvažovalo 47 R (59,5 \%) napříc všemi analyzovanými tř́dami (17 R 4. tř́da, $15 \mathrm{R}$ 5. tř́ida, $13 \mathrm{R} 8$. třída, $2 \mathrm{R} 9$. třída). $\mathrm{V}$ některých $P M$ se objevil směr na rostliny a živočichy a zároveň také na lidskou společnost, společenství ( $9 \mathrm{R}, 11 \%)$. Také se objevila miskoncepce spojené se zrakovou a pocitovou představou evokující společenstvo jako „lidi, kteří se rozhodli změnit svět", či "obchod".

V následných rozhovorech nad některými PM jsme došli i k dalším správným pojetím: „probíhá zmenšování rostlinného společenstva kvůli různé výstavbě a znečištování prírody”; "rostlinné společenstvo se skládá z různých druhů rostlin, kdy každý druh má jiné podmínky pro život". I zde se objevilo pojetí související s lidskou společností, jeden respondent dovysvětlil, že "v biologii jde hlavně o rostlinné a živočišné a že to živočišné se úzce pojí s tím lidským; v ostatních předmětech jde o to lidské".

\section{DOUBRAVA}

$\checkmark$ pojmových mapách (PM) se také objevovala miskoncepce vzniklá na základě podobnosti slova: "výprava" (2 R), "Doubravka"; také se objevila miskoncepce vzniklá kvưli vícevýznamnosti fenoménu: „řeka”, "hora", "hrad”, „jméno". Respondenti často spojovali správně fenomén s lesem ( $22 R, 27,8 \%$ ), ale již se nedostali $k$ dubům, specifikovali spiše vše, co do lesa patří, $v$ jednom př́padě došlo $k$ propojení analyzovaných fenoménů doubrava $\rightarrow$ ekosystém (R ze 4. třídy). Vyskytla se i zajímavá asociační propojení, R z 8. třídy zapojila do své PM i „Dubínka" (pohádkový skřítek žijící v dubu).

$\checkmark$ následných rozhovorech nad některými PM jsme došli již $\mathrm{k}$ výše zmíněným pojetím a miskoncepcím (hora "Doubravka"; les se jmenuje podle kopce "Doubravy"). Jeden z R se šířeji zamýšlel nad těžbou dubového dřeva, výrobou nábytku, až došel k mylnému pojetí "nedobré zacházení s odpady" - během rozhovoru dovysvětlil, že vlastně myslel narůstání množství odpadu (starého nábytku, co lidé vymění za nový).

\section{Fotosyntéza}

V pojmových mapách (PM) se také objevovaly miskoncepce vzniklé špatným pochopením učiva: „přeměna dusíku na kyslík", "vytváří se vzduch", "fotosyntéza je dýchání rostlin". Ve většině př́padů $R$ chyběla v PM nějaká významná složka tohoto procesu $(22 R, 27,8$ $\%)$, nejčastěji glukosa.

V následných rozhovorech nad některými PM jsme došli i k dalším správným pojetím: že je to podmínka života u nás na Zemi, a také že se nedá vyrobit anorganicky, protože by vznikla kyselina uhličitá ( $\mathrm{R}$ z 9 . třídy si uvědomil důležitost př́tomnosti slunečního záření a chloroplastů). Objevila se ovšem i některá další pojetí a miskoncepce, že člověk je schopen fotosyntézy, protože vdechuje oxid uhličitý a produkuje kyslík a glukosu. Díky vhodně voleným otázkám došla $\mathrm{R}$ posléze ke správnému pojetí. Také se objevila miskoncepce vzniklé špatným pochopením učiva či na základě vlastního vysvětlení, že se rostliny procesem fotosyntézy rozmnožují. Nadále R používají nevhodnou terminologii, fotosyntézu popisují, že „rostliny vdechují oxid uhličitý a vydechují kyslík", přimlouvali bychom se ve výuce za terminologii "rostliny přjímají oxid uhličitý a vylučují kyslík". 


\section{Závěr}

Článek zde představil kvalitativní segment výzkumu dětských pojetí, a to tvorbu a reflexi pojmových map osmi fenoménů, které se ukázaly v kvantitativním výzkumu, který předcházel kvalitativnímu, jako nejvíce problematické. Dlužno podotknout, že nikdo ze 79 vybraných respondentů neměl žádnou předchozí zkušenost s použitím pojmové mapy ve výuce, většina vůbec nevěděla, co pojmová či myšlenková mapa je. Po pečlivé instruktáži výzkumníkem a společné tvorbě vzorové pojmové mapy pak ale respondenti byli schopni PM tvořit samostatně. Nejvíce problematické v PM se ukázalo popsat nad směr vedoucí od fenoménu, jak k určitému souvisejícímu pojmu žáci dospěli. Ke stejnému závěru ovšem došly ve svém výzkumu i Schubertová a Bednárová (2018). Ačkoliv byli respondenti v jejich výzkumu, žáci 7. třídy, upozorňováni na nutnost popisků nad šipkami, vyskytovaly se $v$ jejich PM jen zřídka.

Je tedy velká škoda, že práce s pojmovými mapami nejsou do výuky zařazovány častěji. Dle výsledků našeho výzkumu i mnoha dalších (Novak \& Gowin, 1984; Holcomb \& Shonka, 1993; Irvine, 1995; Nuutinen \& Sutinen, 2003; Prokša, 2007; Schubertová \& Bednárová, 2018) podporují u žáků myšlení v souvislostech, odhalují případné miskoncepce (u respondenta z ukázky tvořily miskoncepce jen velmi slušných 17,3 \%) a také proces učení vizualizují.

\section{Poděkování}

Děkujeme vybranému respondentovi a jeho zákonným zástupcům za svolení k publikaci této analýzy rozhovoru.

\section{Použité zdroje}

- $\quad$ Gavora, P. (1996). Výzkumné metody v pedagogice. Brno: Paido.

- Gavora, P. (2010). Úvod do pedagogického výzkumu. 2. vyd. Přeložil Jůva, V., Hlavatá, V. Brno: Paido.

- Hendl, J. (2016). Kvalitativní výzkum: základní teorie, metody a aplikace. Čtvrté, přepracované a rozšírené vydání. Praha: Portál.

- Holcombe, M. \& Shonka, A. (1993). Conceptual mapping: A tool for self-reflection. Clearing House, 67(2), 83-84. Dostupné z: http://search.ebscohost.com/login.aspx?direct $=$ true $\& d b=a 9 h \& a n=9402087869 \&$ scope $=$ site

- Irvine, L. (1995). Can concept mapping be used to promote meaningful learning in nursing education? Journal of Advanced Nursing, 21, 1175-1179. Dostupné z: http://www.academia.edu/29097786/Can concept mapping be used to promote meaningful learning in nurse education

- Novak, J. D. \& Gowin, D. B. (1984). Learning How to Learn. New York: Cambridge University Press.

- Nuutinen, J. A. \& Sutinen, E. (2003). Visualisation of the learning process using concept mapping. Proceedings 3rd IEEE international conference on advanced technologies, Athens, Greece. doi: 10.1109/ICALT.2003.1215117. 
- Pavlátová, V. (2019). Dětská pojetí vybraných environmentálních fenoménů u žáků 1. a 2. stupně základní školy. Ústí nad Labem, disertační práce (Ph.D.). UJEP, Pedagogická fakulta.

- Prokša, M. (2007). Pojmové mapy ako výskumný a diagnostický prostriedok $v$ chemickom vzdelávaní. Dostupné z: http://pdf.truni.sk/zborniky/itpv-2007/Proksa.pdf

- Schubertová, R. \& Bednárová, M. (2018). Využitie pojmového mapovania pri skúmaní predstáv žiakov a študentov o prepojení orgánových sústav. Scientia In Educatione, 9(1), 104-121. Dostupné z: http://www.scied.cz/index.php/scied/issue/viewIssue/111/12

- Strauss, A. L., \& Corbin, J. M. (1999). Základy kvalitativního výzkumu: postupy a techniky metody zakotvené teorie. Brno: Sdružení Podané ruce. 